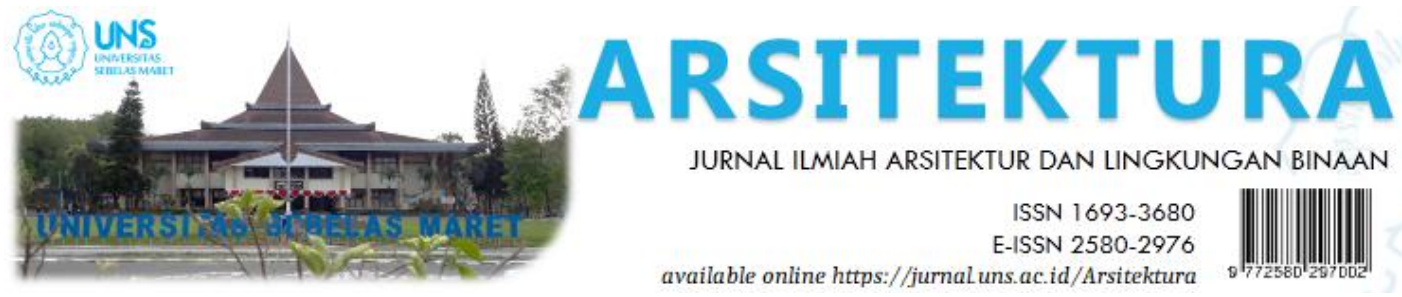

Volume 17 Issue 2 October 2019, pages:271-282

\title{
Tipologi Rumah-Ladang di Desa Enclave Taman Nasional Bromo Tengger Semeru, Ngadas, Kabupaten Malang
}

\section{Typology of Farmhouse in Enclave Village, Bromo Tengger Semeru National Park, Ngadas, Malang Regency}

\author{
Dian Kartika Santoso ${ }^{1 *}$, Antariksa ${ }^{1}$, Sri Utami ${ }^{1}$ \\ ${ }^{1}$ Architecture for Built Environment, Faculty of Engineering Brawijaya University \\ Email : diankartikasantoso@gmail.com
}

DOI: https://doi.org/10.20961/arst.v17i2.33140

Received:July 31, 2019 Revised: October 6, 2019 Accepted: October 6, 2019 Available online: October 31, 2019

\begin{abstract}
Ngadas village is one of the agricultural villages. Ngadas village was an enclave village of Bromo Tengger Semeru National Park (TNBTS). Ngadas people do more activities in the fields than in their homes or dwellings. So, they built a farmhouse around the crop fields. As an agricultural landscape with upland ecology, certainly there have been many human compositions and interventions in its arrangement. It also changed a shaped of farm houses, and now it has a diverse character. So, it is necessary to study the typology of farmhouses in Ngadas Village as an effort to document traditional architecture and Indonesian culture, especially in the upland agrarian community. Qualitative methods have done with a typology approach by grouping similarities and differences based on the form of plans, unit space, layout, space organization, and orientation. The results of the analysis show that there are five types of farmhouses found. A few factors caused by the emergence of the typology of farmhouses in Ngadas Village based on spatial aspects are topographic factors, economic factors, factors in the need for security.
\end{abstract}

Keywords: traditional architecture, farmhouses, typology

\section{PENDAHULUAN}

Indonesia merupakan negara agraris jika dilihat dari mata pencaharian masyarakatnya (Rijal \& Antariksa, 2019). Sistem mata pencaharian masyarakat Indonesia diklasifikasikan menjadi masyarakat pemburu dan peramu, beternak, nelayan, petani ladang, dan petani sawah (Boelaars, 1984; Koentjaraningrat, 2015).

Di Indonesia, Desa Ngadas merupakan salah satu Desa Agraris. Desa Ngadas merupakan salah satu desa yang terletak di dalam (enclave) Taman Nasional Bromo Tengger Semeru
(TNBTS). Letak administrasinya berada di Kecamatan Poncokusumo, Kabupaten Malang, Jawa Timur. Uniknya, penduduk di Desa Ngadas didominasi oleh Suku Tengger (Agustapraja, 2017; Batoro, Setiadi, Chikmawati, \& Purwanto, 2011; BBTNBTS, 2013). Desa Ngadas membentang di antara 1200-2500 meter di atas permukaan laut (mdpl) pada lereng Gunung Semeru (Agustapraja, 2017; Anggiana \& Bergas, 2014; Budiyanti, 2015; Endarwati, 2013).

Dengan kondisi lanskapnya, Ngadas dikenal sebagai Desa penghasil sayur mayur 
(Agustapraja, 2017; Anggiana \& Bergas, 2014; Batoro et al., 2011; Endarwati, 2013; Listiyana \& Mutiah, 2017). Penduduk Ngadas merupakan petani ladang yang tangguh dan bertempat tinggal berkelompok di bukit-bukit (Supanto, 2016; Sutarto, 2006). Ketergantungan masyarakat dengan lahan pertanian membuat Ngadas memiliki citra agraris yang kuat (Subadyo, 2016). Sama halnya dengan masyarakat peladang yang lain, seperti masyarakat kasepuhan sunda maupun madura, lanskap agrikultur terletak di luar kawasan permukiman yang mengelompok (Febrianto, Wulandari, \& Santosa, 2017). Namun, terdapat perbedaan pola aktivitas dalam bercocok tanam dan berhuni.

Masyarakat Ngadas lebih banyak melakukan aktivitas di ladang daripada di dalam rumah atau hunian mereka (Batoro, 2017; BBTNBTS, 2013). Sehingga, masyarakat mendirikan rumah rumah ladang yang disebut gubuk di sekitar ladang tempat mereka bercocok tanam (Batoro, 2017). Hal ini menjadi satu hal yang menarik dan belum banyak digali oleh para peneliti. Dalam beberapa kebudayaan, terutama budaya agraris gubuk atau rumah-ladang merupakan elemen penting bagi keberlangsungan hidup masyarakat (Picuno, 2012; Susperregi, Telleria, Urteaga, \& Jansma, 2017). Uniknya, setiap keluarga memiliki satu gubuk atau rumah-ladang di ladang mereka. Oleh karena itu, keberlangsungan hidup di Desa Ngadas juga tergantung dari keberlangsungan pertanian, termasuk rumah-ladang.

Penelitian mengenai rumah-ladang dan lanskap agrikultur juga sebenarnya telah dilakukan beberapa peneliti terdahulu, tetapi mayoritas dikerjakan di luar negeri. Penelitian mengenai tipologi misalnya telah dilakukan oleh Picuno et.al (Picuno, 2012) yang sebenarnya jauh berbeda dengan penelitian yang akan dilakukan ini. Di Indonesia sendiri, rumah-ladang yang pernah cukup banyak di bahas adalah Leuit, yang notabene hanyalah salah satu fungsi yang ada di rumah-ladang di Ngadas serta letaknya tidak satu kesatuan dengan lanskap agrikulturnya (Nopianti, 2016).

Sebagai sebuah lanskap agrikultur dengan ekologi tegalan, tentu telah banyak gubahan dan campur tangan manusia dalam penataannya. Hal ini membuat rumah ladang juga banyak berubah, dan kini memiliki karakter yang beragam. Sehingga, perlu adanya kajian tipologi rumah ladang di Desa Ngadas sebagai upaya pendokumentasian arsitektur tradisional dan kebudayaan Indonesia khususnya masyarakat agraris pegunungan.

\section{METODE}

Penelitian ini dilakukan dengan metode kualitatif. Karakteristik utama dari penelitian kualitatif berdasarkan latar belakang alami/kenyataan yang ada di masyarakat. Langkah yang biasa digunakan dalam metode penelitian kualitatif adalah pengamatan lapang, wawancara, dan penelaahan data. Penyajian dan analisis data yang dilakukan dalam penelitian kualitatif dilakukan secara naratif (Creswell, 2014; Groat \& Wang, 2013; Sugiyono, 2016).

Langkah-langkah yang dilakukan dalam penelitian ini mencakup proses studi pendahuluan, identifikasi, analisis, serta penarikan kesimpulan seperti tercantum pada Tabel 1.

Tabel 1. Tahapan penelitian

\begin{tabular}{|c|c|c|}
\hline & Tahap & Teknik Pengambilan Data \\
\hline 1 & $\begin{array}{l}\text { Studi } \\
\text { Pendahuluan }\end{array}$ & $\begin{array}{l}\text { Penelusuran melalui internet, } \\
\text { jurnal dan buku yang terkait } \\
\text { dengan lokasi dan topik studi. }\end{array}$ \\
\hline 2 & Identifikasi & $\begin{array}{l}\text { Pemilihan sampel rumah- } \\
\text { ladang yang akan diteliti } \\
\text { didasarkan pada beberapa } \\
\text { kriteria seperti: } \\
\text { a.Objek menjadi satu kesatuan } \\
\text { dengan lanskap agrikultur } \\
\text { berupa ekologi tegalan } \\
\text { b.Objek berada pada } \\
\text { ketinggian optimal ekologi } \\
\text { tegal yaitu 1000-2000 mdpl } \\
\text { c.Objek telah mengalami } \\
\text { perubahan pola dan tatanan } \\
\text { dari awal berdirinya rumah } \\
\text { ladang. Kondisi awal rumah- } \\
\text { ladang didapatkan melalui } \\
\text { metode mental mapping } \\
\text { terhadap warga Desa Ngadas. } \\
\text { d.Objek memiliki tiga unit } \\
\text { ruang minimal yang harus } \\
\text { dimiliki oleh rumah-ladang } \\
\text { yaitu ruang untuk ditempati }\end{array}$ \\
\hline
\end{tabular}




\begin{tabular}{|c|c|c|}
\hline No & Tahap & Teknik Pengambilan Data \\
\hline & & $\begin{array}{l}\text { petani, ruang untuk } \\
\text { penyimpanan alat pertanian, } \\
\text { dan kandang. } \\
\text { e.Objek masih ditinggali } \\
\text { petani pada waktu tertentu } \\
\text { f.Objek dianggap mewakili } \\
\text { situasi objek penelitian dan } \\
\text { mewakili ragam rumah-ladang } \\
\text { yang ada di Desa Ngadas. } \\
\text { g.Kondisi sosial-budaya } \\
\text { pemilik rumah-ladang. Hal ini } \\
\text { terkait dengan pemahaman } \\
\text { terhadap nilai-nilai budaya } \\
\text { maupun historis dari rumah- } \\
\text { ladang. }\end{array}$ \\
\hline 3 & Analisis & $\begin{array}{lcr}\text { Analisis } & \text { dilakukan } & \text { sesuai } \\
\text { dengan } & \text { variabel } & \text { yang } \\
\text { ditentukan } & \text { melalui } & \text { kajian } \\
\text { pustaka (Gambar 1) } & \\
\text { Langkah } & \text { selanjutnya } \\
\text { mengelompokkan kesamaan } \\
\text { dan perbedaan tiap variabel } \\
\text { sehingga terdapat kejelasan } \\
\text { tipe-tipe yang ditemukan. }\end{array}$ \\
\hline 4 & Kesimpulan & $\begin{array}{ll}\text { Tipologi berdasarkan variabel } \\
\text { yang ditemukan } \\
\text { Menyusun } \\
\text { rekomendasi }\end{array}$ \\
\hline
\end{tabular}

Variabel penelitian yang menjadi acuan dalam penentuan tipologi rumah-ladang didasarkan pada aspek keruangan. Teori yang ditemukan melalui proses kajian pustaka seperti pada Gambar 1.

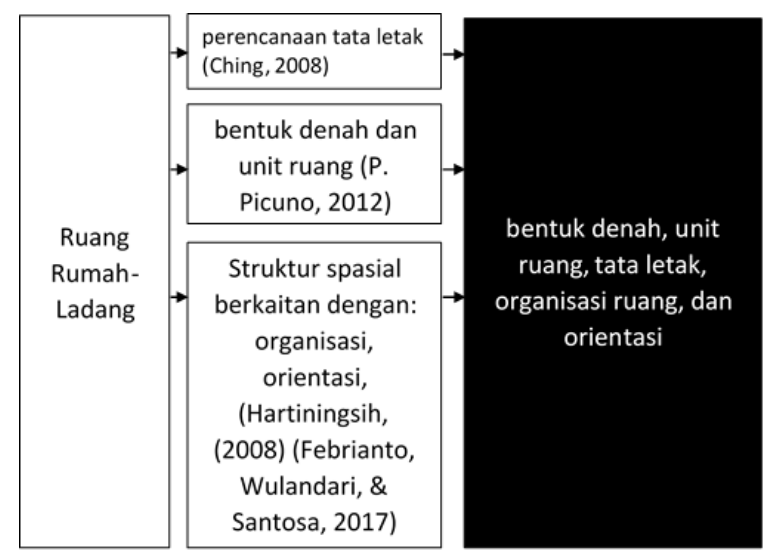

Gambar 1. Pemilihan Variabel Penelitian
Jadi, variabel yang dilihat dalam penentuan tipologi adalah bentuk denah, unit ruang, tata letak, organisasi ruang, dan orientasi.

Penelitian dilakukan di Desa Ngadas yang letak administrasinya di Kecamatan Poncokusumo, Kabupaten Malang, (lihat pada Gambar 2).

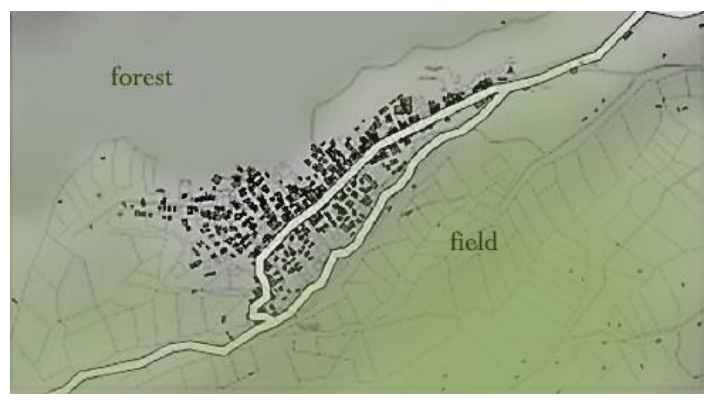

Gambar 2. Peta Desa Ngadas

\section{HASIL DAN PEMBAHASAN}

\subsection{Hasil Pemilihan Sampel}

Pemilihan sampel yang didasarkan pada perubahan yang sudah terjadi, sehingga perlu metode untuk mengidentifikasi kondisi awal dari rumah-ladang.

Mental mapping digunakan untuk memperoleh gambaran artefak yang sudah tidak dapat lagi ditemukan. Mental mapping sendiri merupakan metode yang digunakan untuk mendapatkan persepsi dan sudut pandang seseorang tentang bidang interaksi mereka(Lahav \& Mioduser, 2008; Majerova, 2015). Dalam hal ini objek yang digambarkan adalah rumah ladang.

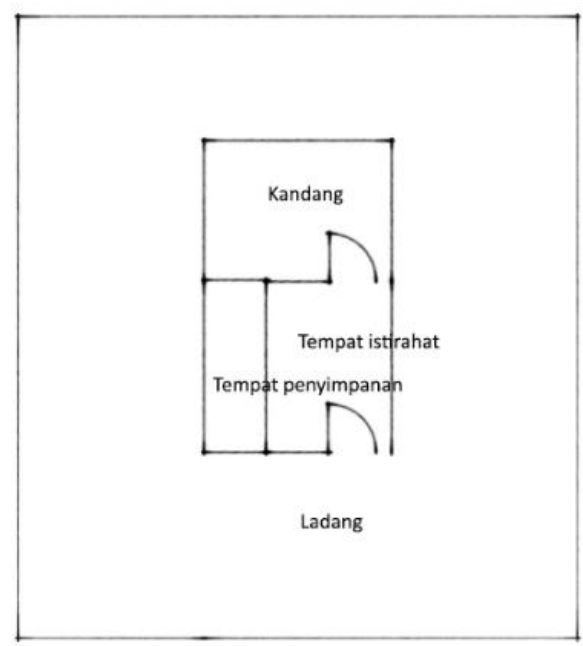

Gambar 3. Denah Awal Rumah-Ladang di Desa Ngadas 
Gambar di atas menjadi acuan peneliti dalam menentukan sampel. Observasi lapang pada tahap awal, peneliti menemukan 10 rumah ladang yang menjadi kesatuan dengan lanskap agrikulturnya. Rumah-ladang beserta lanskap agrikulturnya tersebut yang akan menjadi sampel penelitian.

\subsection{Hasil Identifikasi Aspek Keruangan}

Identifikasi dilakukan pada 10 rumah-ladang. Hal-hal yang menjadi unit amatan adalah bentuk denah, unit ruang, tata letak, organisasi ruang, dan orientasi.

\section{a. Sampel 01}

Sampel pertama memiliki karakter denah dengan berbentuk L dan semua unit ruang (kandang, tempat alat pertanian, dan tempat istirahat petani). Tata letak di dalam rumah ladang memiliki karakter seluruh ruang menyatu dalam satu atap dan berorientasi pada ladang milik penghuni rumah.Seperti yang terlihat pada Gambar 4.

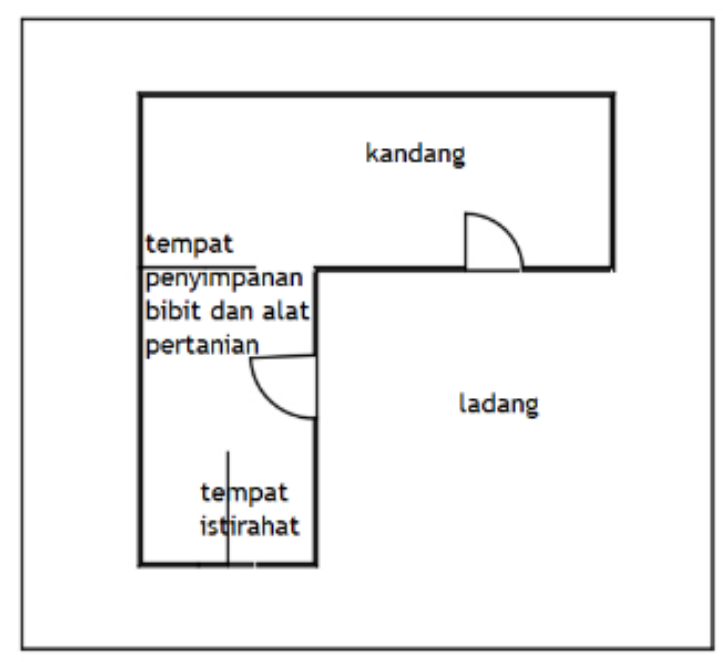

Gambar 4. Denah Sampel 1

\section{b. Sampel 02}

Sampel kedua memiliki karakter denah berbentuk persegi panjang. Memiliki tiga unit ruang (kandang, tempat alat pertanian, dan tempat istirahat petani). Letak kandang terpisah di belakang ruang utama yaitu ruang penyimpanan dan ruang istirahat. Orientasi rumah ladang menghadap ladang milik penghuni rumah. Seperti yang terlihat pada Gambar 5.

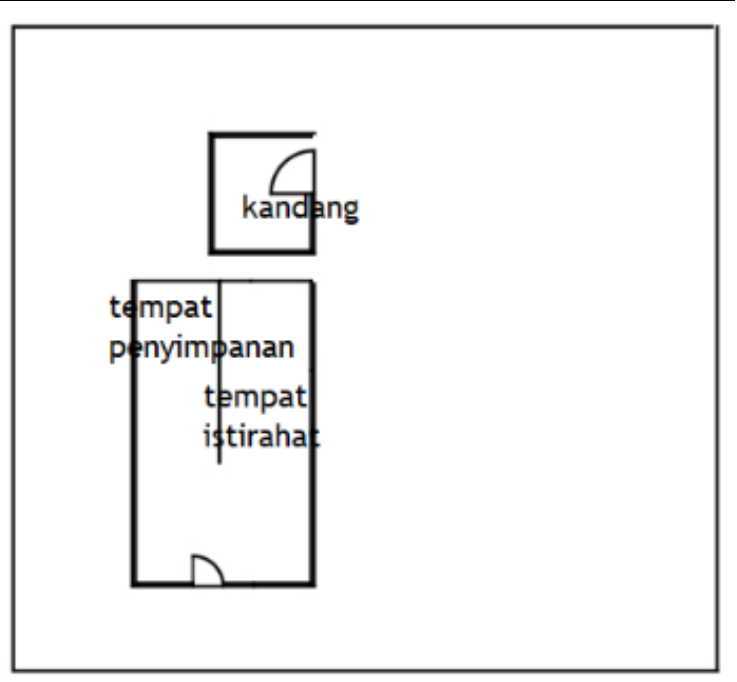

Gambar 5. Denah Sampel 2

\section{c. Sampel 03}

Sampel ketiga memiliki karakter denah persegi panjang dengan berbentuk $\mathrm{L}$ dan semua unit ruang (kandang, tempat alat pertanian, dan tempat istirahat petani). Tata letak di dalam rumah ladang memiliki karakter seluruh ruang menyatu dalam satu atap dan berorientasi pada ladang milik penghuni rumah. Seperti yang terlihat pada Gambar 6.

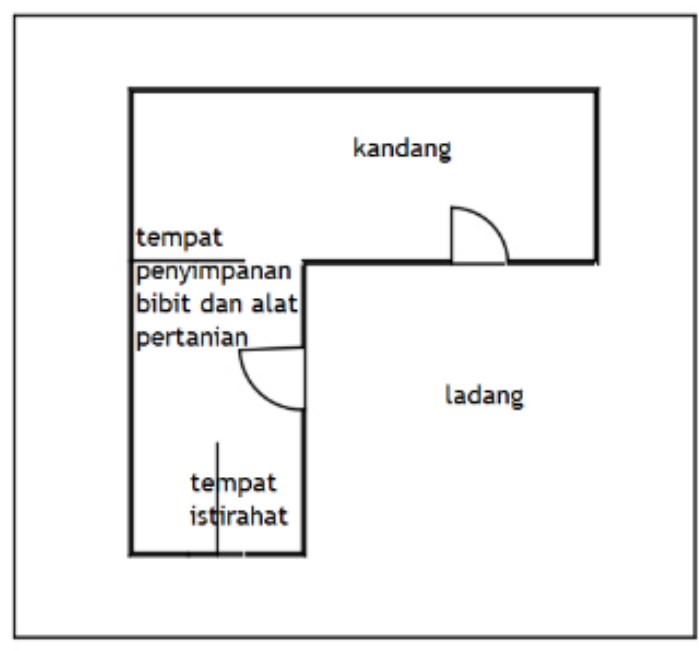

Gambar 6. Denah Sampel 3 


\section{d. Sampel 04}

Sampel keempat memiliki denah dengan pola persegi panjang. Unit ruang berupa kandang terpisah di belakang ruangan utama yaitu tempat penyimpanan dan tempat beristirahat. Orientasi rumah ladang menghadap ladang milik penghuni rumah. Seperti yang terlihat pada Gambar 7.

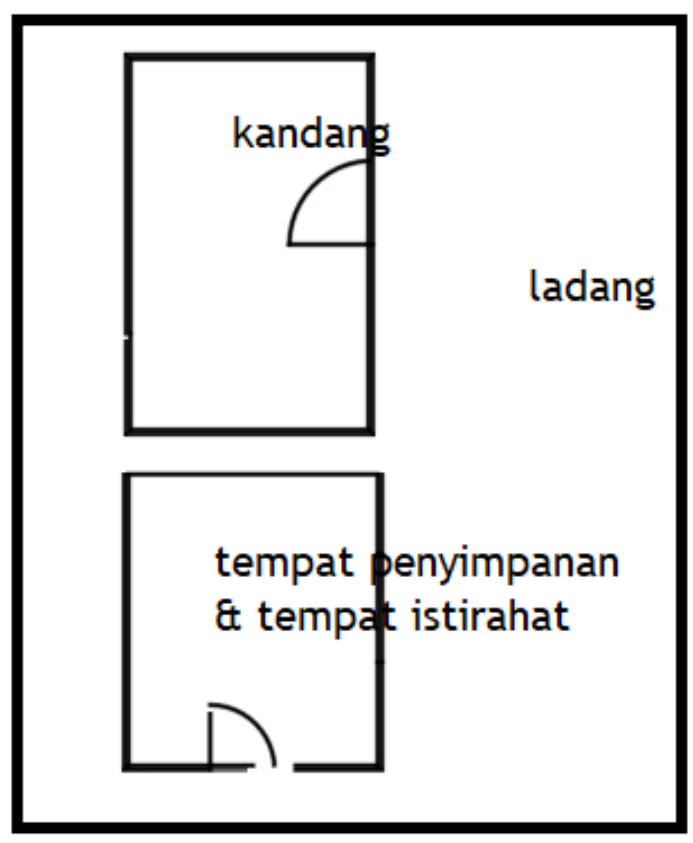

Gambar 7. Denah Sampel 4

\section{e. Sampel 05}

Sampel kelima memiliki denah dengan pola persegi panjang. Unit ruang berupa kandang terpisah di belakang ruangan utama yaitu tempat penyimpanan dan tempat beristirahat. Orientasi rumah ladang menghadap ladang milik penghuni rumah. Seperti yang terlihat pada Gambar 8.

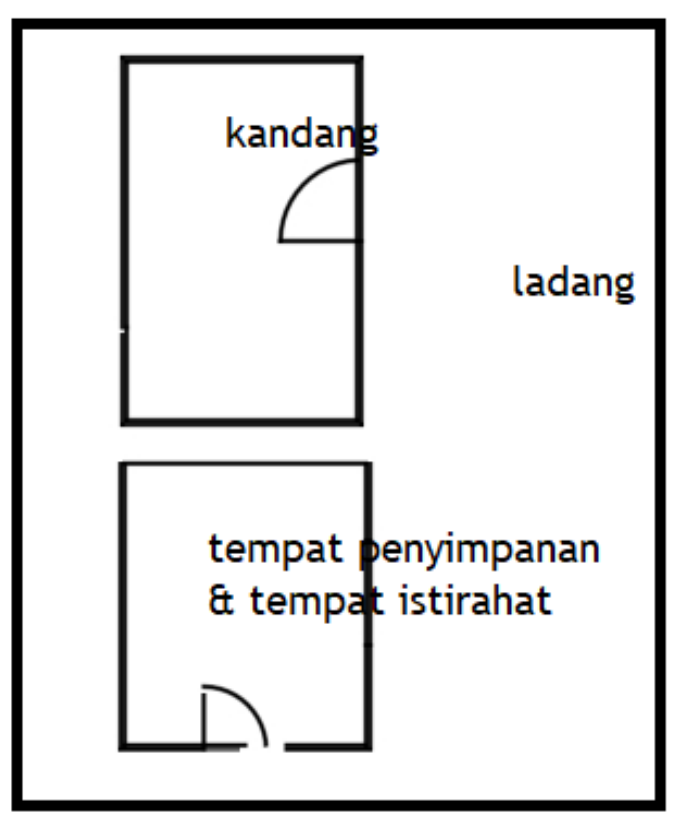

Gambar 8. Denah Sampel 5

\section{f. Sampel 06}

Sampel keenam memiliki denah dengan pola persegi panjang. Unit ruang berupa kandang terpisah jauh dari ruangan utama yaitu tempat penyimpanan dan tempat beristirahat namun masih dapat diamati dari rumah-ladang. Orientasi rumah ladang menghadap ladang milik penghuni rumah. Seperti yang terlihat pada Gambar 9.

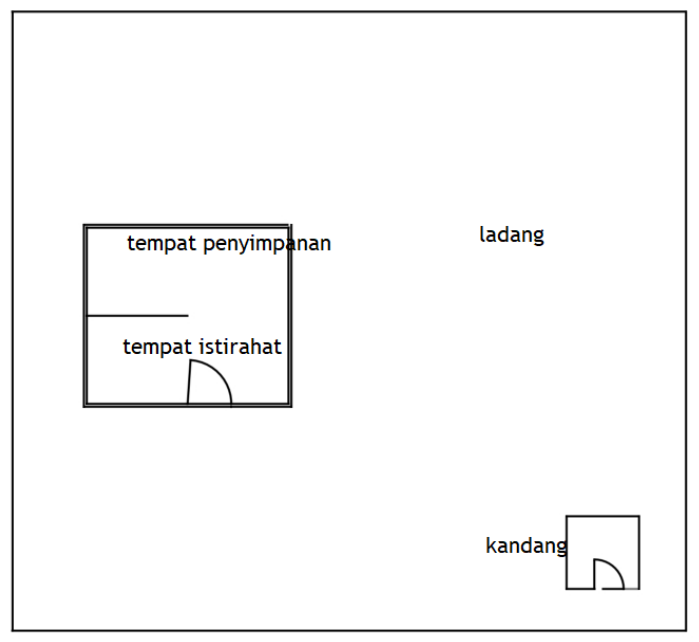

Gambar 9. Denah Sampel 6 


\section{g. Sampel 07}

Sampel ketujuh memiliki denah dengan pola persegi panjang. Unit ruang berupa kandang terpisah jauh dari ruangan utama yaitu tempat penyimpanan dan tempat beristirahat namun masih dapat diamati dari rumah-ladang. Orientasi rumah ladang menghadap ladang milik penghuni rumah. Seperti yang terlihat pada Gambar 10.

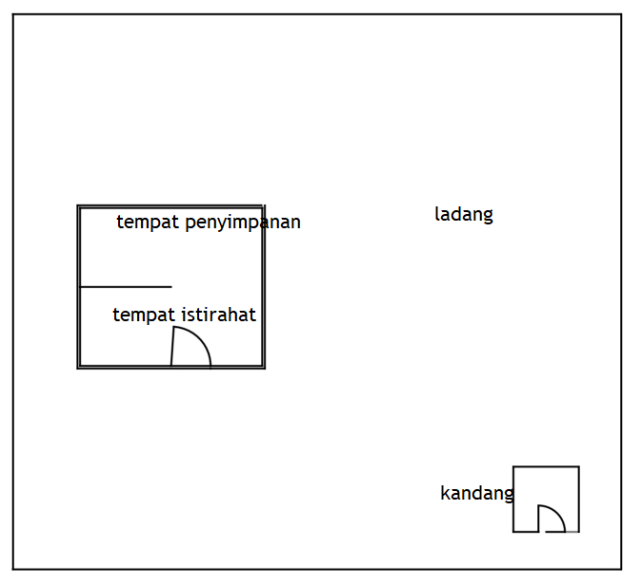

Gambar 10. Denah Sampel 6

\section{h. Sampel 08}

Sampel ke delapan memiliki denah dengan pola persegi panjang. Unit ruang berupa kandang terpisah jauh dari ruangan utama yaitu tempat penyimpanan dan tempat beristirahat namun masih dapat diamati dari rumah-ladang. Orientasi rumah ladang menghadap ladang milik penghuni rumah. Seperti yang terlihat pada Gambar 11.

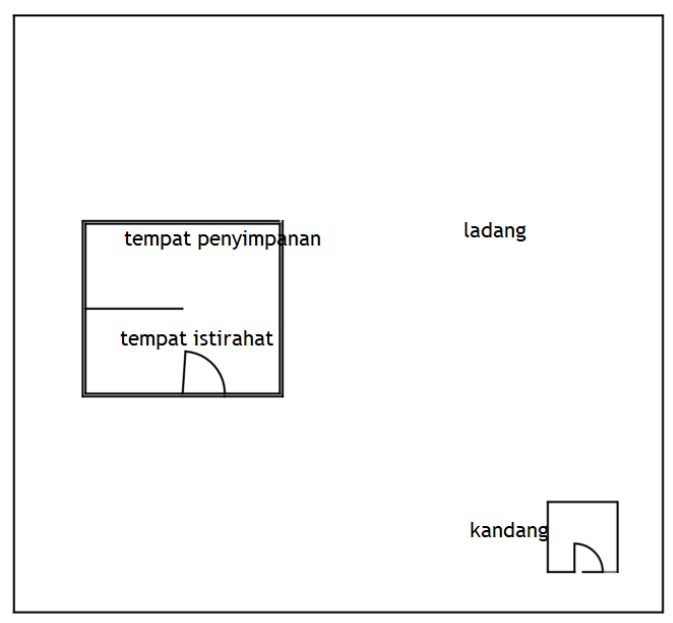

Gambar 11. Denah Sampel 8

\section{i. Sampel 09}

Sampel ke sembilan memiliki denah dengan pola persegi panjang. Unit ruang berupa kandang terpisah berada di samping dari ruangan utama yaitu tempat penyimpanan dan tempat beristirahat. Orientasi rumah ladang. Seperti yang terlihat pada Gambar 12.

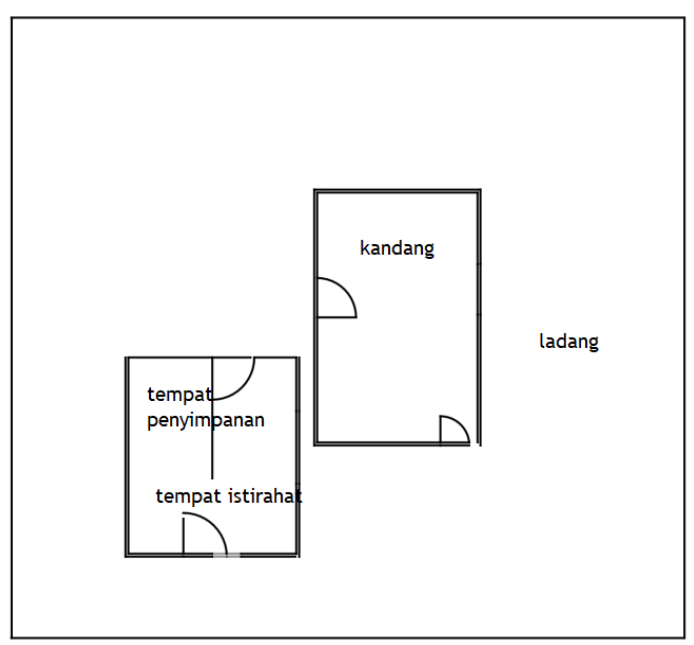

Gambar 12. Denah Sampel 8

\section{j. Sampel 10}

Sampel kesepuluh memiliki denah dengan pola persegi panjang. Unit ruang berupa kandang terpisah di depan ruangan utama yaitu tempat penyimpanan dan tempat beristirahat. Orientasi rumah ladang menghadap ladang milik penghuni rumah. Seperti yang terlihat pada Gambar 13.

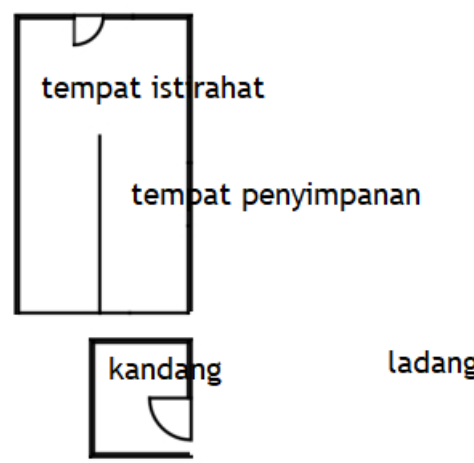

Gambar 13. Denah Sampel 14 


\subsection{Hasil Analisis}

Sepuluh sampel dikelompokkan berdasarkan kesamaan dan perbedaan pada setiap variabel sehingga di temukan beberapa tipologi yang tergambar pada Tabel 3.

Tabel 2. Analisis Tipologi

\begin{tabular}{|c|c|c|c|c|}
\hline $\mathbf{N}$ & $\begin{array}{c}\text { Bentuk } \\
\text { denah }\end{array}$ & $\begin{array}{l}\text { Unit } \\
\text { ruang }\end{array}$ & $\begin{array}{c}\text { Tata } \\
\text { letak/orga } \\
\text { nisasi } \\
\text { ruang }\end{array}$ & $\begin{array}{c}\text { Orienta } \\
\text { si }\end{array}$ \\
\hline $\begin{array}{l}0 \\
1\end{array}$ & $\begin{array}{l}\text { Berbent } \\
\text { uk L } \\
\text { memanj } \\
\text { ang }\end{array}$ & $\begin{array}{l}\text { Memil } \\
\text { iki } 3 \\
\text { unit } \\
\text { ruang } \\
\text { kanda } \\
\text { ng, } \\
\text { tempat } \\
\text { alat } \\
\text { pertani } \\
\text { an, } \\
\text { dan } \\
\text { tempat } \\
\text { istirah } \\
\text { at } \\
\text { petani }\end{array}$ & $\begin{array}{l}\text { Tata letak } \\
\text { di dalam } \\
\text { rumah } \\
\text { ladang } \\
\text { memiliki } \\
\text { karakter } \\
\text { seluruh } \\
\text { ruang } \\
\text { menyatu } \\
\text { dalam satu } \\
\text { atap }\end{array}$ & $\begin{array}{l}\text { Mengha } \\
\text { dap } \\
\text { ladang } \\
\text { milik } \\
\text { penghu } \\
\text { ni } \\
\text { rumah }\end{array}$ \\
\hline $\begin{array}{l}0 \\
2\end{array}$ & $\begin{array}{l}\text { Berbent } \\
\text { uk } \\
\text { persegi } \\
\text { panjang }\end{array}$ & $\begin{array}{l}\text { Memil } \\
\text { iki } 3 \\
\text { unit } \\
\text { ruang } \\
\text { kanda } \\
\text { ng, } \\
\text { tempat } \\
\text { alat } \\
\text { pertani } \\
\text { an, } \\
\text { dan } \\
\text { tempat } \\
\text { istirah } \\
\text { at } \\
\text { petani }\end{array}$ & $\begin{array}{l}\text { Letak } \\
\text { kandang } \\
\text { terpisah di } \\
\text { belakang } \\
\text { ruang } \\
\text { utama yaitu } \\
\text { ruang } \\
\text { penyimpan } \\
\text { an dan } \\
\text { ruang } \\
\text { istirahat. } \\
\text { Orientasi }\end{array}$ & $\begin{array}{l}\text { Mengha } \\
\text { dap } \\
\text { ladang } \\
\text { milik } \\
\text { penghu } \\
\text { ni } \\
\text { rumah }\end{array}$ \\
\hline $\begin{array}{l}0 \\
3\end{array}$ & $\begin{array}{l}\text { Berbent } \\
\text { uk L } \\
\text { memanj } \\
\text { ang }\end{array}$ & $\begin{array}{l}\text { Memil } \\
\text { iki } 3 \\
\text { unit } \\
\text { ruang } \\
\text { kanda } \\
\text { ng, } \\
\text { tempat } \\
\text { alat }\end{array}$ & $\begin{array}{l}\text { Tata letak } \\
\text { di dalam } \\
\text { rumah } \\
\text { ladang } \\
\text { memiliki } \\
\text { karakter } \\
\text { seluruh } \\
\text { ruang }\end{array}$ & $\begin{array}{l}\text { Mengha } \\
\text { dap } \\
\text { ladang } \\
\text { milik } \\
\text { penghu } \\
\text { ni } \\
\text { rumah }\end{array}$ \\
\hline
\end{tabular}

\begin{tabular}{|c|c|c|c|c|}
\hline $\begin{array}{l}\mathbf{N} \\
\mathbf{o}\end{array}$ & $\begin{array}{c}\text { Bentuk } \\
\text { denah }\end{array}$ & $\begin{array}{l}\text { Unit } \\
\text { ruang }\end{array}$ & $\begin{array}{c}\text { Tata } \\
\text { letak/orga } \\
\text { nisasi } \\
\text { ruang }\end{array}$ & $\begin{array}{c}\text { Orienta } \\
\text { si }\end{array}$ \\
\hline & & $\begin{array}{l}\text { pertani } \\
\text { an, } \\
\text { dan } \\
\text { tempat } \\
\text { istirah } \\
\text { at } \\
\text { petani }\end{array}$ & $\begin{array}{l}\text { menyatu } \\
\text { dalam satu } \\
\text { atap }\end{array}$ & \\
\hline $\begin{array}{l}0 \\
4\end{array}$ & $\begin{array}{l}\text { Berbent } \\
\text { uk } \\
\text { persegi } \\
\text { panjang }\end{array}$ & $\begin{array}{l}\text { Memil } \\
\text { iki } 3 \\
\text { unit } \\
\text { ruang } \\
\text { kanda } \\
\text { ng, } \\
\text { tempat } \\
\text { alat } \\
\text { pertani } \\
\text { an, } \\
\text { dan } \\
\text { tempat } \\
\text { istirah } \\
\text { at } \\
\text { petani }\end{array}$ & $\begin{array}{l}\text { Unit ruang } \\
\text { berupa } \\
\text { kandang } \\
\text { terpisah di } \\
\text { belakang } \\
\text { ruangan } \\
\text { utama yaitu } \\
\text { tempat } \\
\text { penyimpan } \\
\text { an dan } \\
\text { tempat }\end{array}$ & $\begin{array}{l}\text { Mengha } \\
\text { dap } \\
\text { ladang } \\
\text { milik } \\
\text { penghu } \\
\text { ni } \\
\text { rumah }\end{array}$ \\
\hline $\begin{array}{l}0 \\
5\end{array}$ & $\begin{array}{l}\text { Berbent } \\
\text { uk } \\
\text { persegi } \\
\text { panjang }\end{array}$ & $\begin{array}{l}\text { Memil } \\
\text { iki } 3 \\
\text { unit } \\
\text { ruang } \\
\text { kanda } \\
\text { ng, } \\
\text { tempat } \\
\text { alat } \\
\text { pertani } \\
\text { an, } \\
\text { dan } \\
\text { tempat } \\
\text { istirah } \\
\text { at } \\
\text { petani }\end{array}$ & $\begin{array}{l}\text { Unit ruang } \\
\text { berupa } \\
\text { kandang } \\
\text { terpisah di } \\
\text { belakang } \\
\text { ruangan } \\
\text { utama yaitu } \\
\text { tempat } \\
\text { penyimpan } \\
\text { an dan } \\
\text { tempat } \\
\text { beristirahat. }\end{array}$ & $\begin{array}{l}\text { Mengha } \\
\text { dap } \\
\text { ladang } \\
\text { milik } \\
\text { penghu } \\
\text { ni } \\
\text { rumah }\end{array}$ \\
\hline $\begin{array}{l}0 \\
6\end{array}$ & $\begin{array}{l}\text { Berbent } \\
\text { uk } \\
\text { persegi } \\
\text { panjang }\end{array}$ & $\begin{array}{l}\text { Memil } \\
\text { iki } 3 \\
\text { unit } \\
\text { ruang } \\
\text { kanda } \\
\text { ng, } \\
\text { tempat } \\
\text { alat } \\
\text { pertani }\end{array}$ & $\begin{array}{l}\text { Unit ruang } \\
\text { berupa } \\
\text { kandang } \\
\text { terpisah } \\
\text { jauh dari } \\
\text { ruangan } \\
\text { utama yaitu } \\
\text { tempat } \\
\text { penyimpan }\end{array}$ & $\begin{array}{l}\text { Mengha } \\
\text { dap } \\
\text { ladang } \\
\text { milik } \\
\text { penghu } \\
\text { ni } \\
\text { rumah }\end{array}$ \\
\hline
\end{tabular}




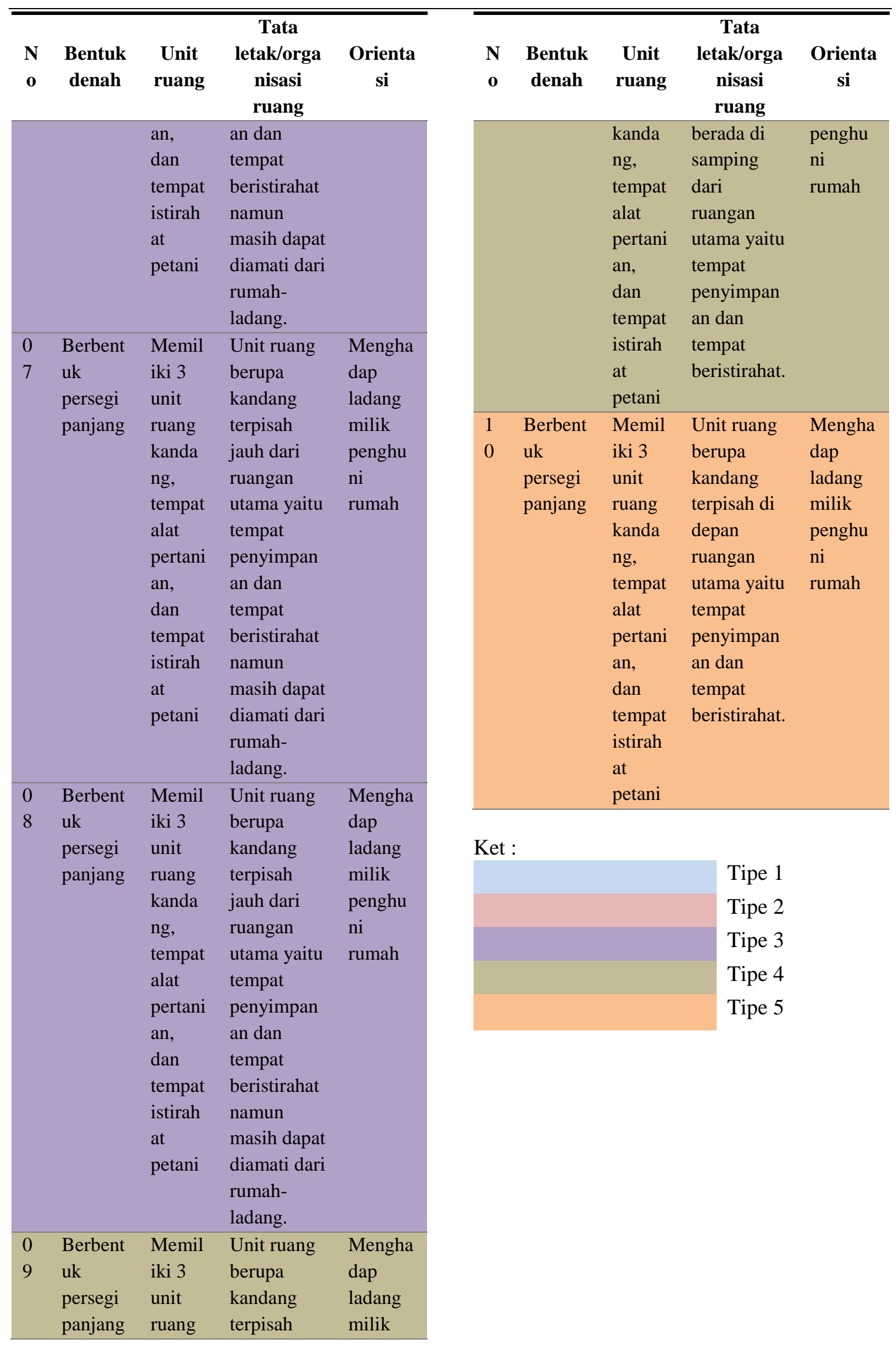




\subsection{Fungsi Ruang}

Rumah-ladang memiliki tiga unit ruang yaitu tempat penyimpanan alat pertanian dan bibit, tempat istirahat, dan kandang. Ruang penyimpanan digunakan untuk menyimpan alat pertanian dan bibit (Gambar 14).

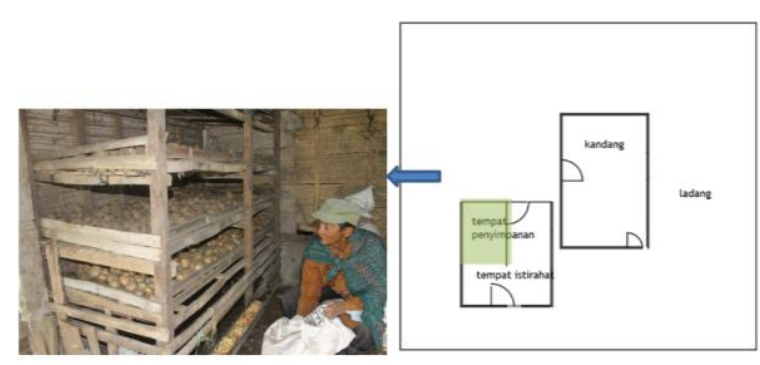

Gambar 14. Tempat penyimpanan

Ruang istirahat digunakan untuk makan dan minum serta aktivitas gegenen ketika musim penghujan (Gambar 15).

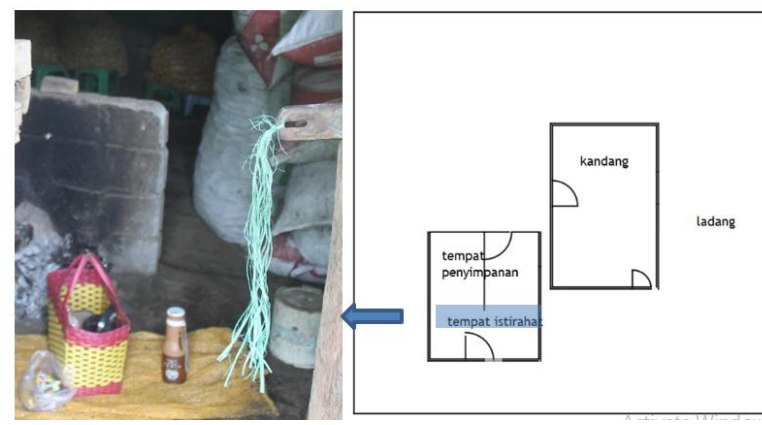

Gambar 15. Tempat beristirahat

Kandang (Gambar 16) digunakan untuk menyimpan hewan ternak. Terdapat dua hewan ternak utama yang dipelihara di Ngadas yaitu kuda dan babi.

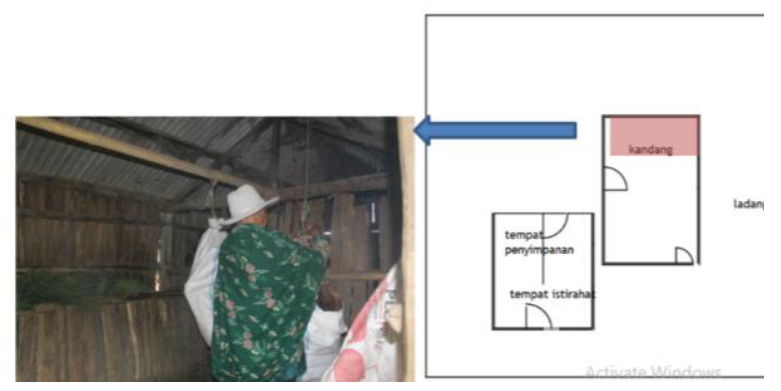

Gambar 16. Kandang kuda
Setiap ruangan yang terdapat di rumah-ladang merupakan satuan penting dalam menunjang kegiatan pertanian. Karena pentingnya pertanian juga, maka orientasi atau arah hadap dari rumah ladang selalu menghadap ke ladang pertanian dan terletak di daerah yang relatif lebih landai atau datar.

\subsection{Pembahasan}

Hasil analisis menunukkan ada lima tipe rumah-ladang yang ditemukan. Tipe pertama adalah karakter denah dengan berbentuk $\mathrm{L}$ dan semua unit ruang (kandang, tempat alat pertanian, dan tempat istirahat petani). Tata letak di dalam rumah ladang memiliki karakter seluruh ruang menyatu dalam satu atap dan berorientasi pada ladang milik penghuni rumah.

Tipe kedua memiliki karakter denah berbentuk persegi panjang. Memiliki tiga unit ruang (kandang, tempat alat pertanian, dan tempat istirahat petani). Letak kandang terpisah di belakang ruang utama yaitu ruang penyimpanan dan ruang istirahat. Orientasi rumah ladang menghadap ladang milik penghuni rumah.

Tipe ketiga memiliki denah dengan pola persegi panjang. Unit ruang berupa kandang terpisah jauh dari ruangan utama yaitu tempat penyimpanan dan tempat beristirahat namun masih dapat diamati dari rumah-ladang. Orientasi rumah ladang menghadap ladang milik penghuni rumah.

Tipe keempat memiliki denah dengan pola persegi panjang. Unit ruang berupa kandang terpisah berada di samping dari ruangan utama yaitu tempat penyimpanan dan tempat beristirahat. Orientasi rumah ladang menghadap ladang milik penghuni rumah.

Tipe kelima memiliki denah dengan pola persegi panjang. Unit ruang berupa kandang terpisah di depan ruangan utama yaitu tempat penyimpanan dan tempat beristirahat. Orientasi rumah ladang menghadap ladang milik penghuni rumah.

Perbedaan tipe ini disebabkan oleh beberapa hal. Hal utama yang menyebabkan adalah kondisi topografi. Topografi ladang di Desa Ngadas sangat curam (Subadyo, 2016). Rumahladang dibangun pada kondisi kelerengan yang paling memungkinkan di lahan datar. Karena, 
pada dasarnya manusia bertahan dan akan memilih tinggal di lereng yang datar untuk memudahkan aktivitas mereka (Rave-Arango \& Blandón-Uribe, 2012). Jika petani tidak memiliki cukup lahan yang datar, Rumah ladang terbagi menjadi dua bagian yang terpisah. Satu bagian terdiri dari ruang penyimpanan dan tempat istirahat, satu ruangan terdiri dari kandang.

Faktor lain penyebab perbedaan tipologi adalah komoditi ternak yang berbeda. Kuda dan babi merupakan komoditi utama. Babi membutuhkan kandang dengan sanitasi yang baik, sehingga kandang babi selalu diletakkan berjauhan (Parera \& Jacob, 2016) dengan ruangan utama rumah-ladang. Sementara itu, komoditi kuda yang bernilai ekonomi tinggi diletakkan berada di dekat dengan ruangan utama karena faktor keamanan.

Orientasi rumah-ladang yang menghadap ke arah ladang juga bertujuan untuk mengawasi ladang dari gangguan. Faktor keamanan adalah faktor utama yang menjadi pertimbangan arah orientasi rumah-ladang. Hal ini sesuai dengan kebutuhan dasar manusia berupa rasa aman di suatu lingkungan tertentu (Cheng \& Kuo, 2015; Downey, Threlkeld, \& Warburton, 2017).

Jadi, dapat disimpulkan bahwa faktor penyebab munculnya tipologi rumah-ladang di Desa Ngadas berdasarkan aspek keruangan adalah faktor topografi, faktor ekonomi, faktor kebutuhan akan rasa aman.

\section{KESIMPULAN}

Terdapat lima tipe rumah-ladang di Desa Ngadas berdasarkan aspek keruangan. Tipe pertama adalah karakter denah dengan berbentuk L dan semua unit ruang (kandang, tempat alat pertanian, dan tempat istirahat petani). Tata letak di dalam rumah ladang memiliki karakter seluruh ruang menyatu dalam satu atap dan berorientasi pada ladang milik penghuni rumah. Tipe kedua memiliki karakter denah berbentuk persegi panjang. Memiliki tiga unit ruang (kandang, tempat alat pertanian, dan tempat istirahat petani). Letak kandang terpisah di belakang ruang utama yaitu ruang penyimpanan dan ruang istirahat. Orientasi rumah ladang menghadap ladang milik penghuni rumah. Tipe ketiga memiliki denah dengan pola persegi panjang. Unit ruang berupa kandang terpisah jauh dari ruangan utama yaitu tempat penyimpanan dan tempat beristirahat namun masih dapat diamati dari rumah-ladang. Orientasi rumah ladang menghadap ladang milik penghuni rumah.Tipe keempat memiliki denah dengan pola persegi panjang. Unit ruang berupa kandang terpisah berada di samping dari ruangan utama yaitu tempat penyimpanan dan tempat beristirahat. Orientasi rumah ladang menghadap ladang milik penghuni rumah. Tipe kelima memiliki denah dengan pola persegi panjang. Unit ruang berupa kandang terpisah di depan ruangan utama yaitu tempat penyimpanan dan tempat beristirahat. Orientasi rumah ladang menghadap ladang milik penghuni rumah. Faktor penyebab munculnya tipologi rumahladang di Desa Ngadas berdasarkan aspek keruangan adalah faktor topografi, faktor ekonomi, faktor kebutuhan akan rasa aman. Perlu banyak penelitian lain mengenai tipologi rumah-ladang pada aspek-aspek lainnya. 


\section{REFERENSI}

Ayu, D., Antariksa, \& Ridjal, A. M. (2015). Aktivitas Ritual Pembentuk Teritori Ruang pada Pesarean Gunung Kawi Kabupaten Malang. Jurnal Arsitektur NALARs Januari, Volume 14 (No 1), 1320.

Cheng, C.-K., \& Kuo, H.-Y. (2015). Bonding to a new place never visited: Exploring the relationship between landscape elements and place bonding. Tourism Management, $\quad 46, \quad 546-560$. doi:10.1016/j.tourman.2014.08.006

Creswell, J. W. (2014). Research design : qualitative, quantitative, and mixed methods approaches (4 ed.). New Delhi: SAGE Publications

Downey, H., Threlkeld, G., \& Warburton, J. (2017). What is the role of place identity in older farming couples' retirement considerations? Journal of Rural Studies, 50 , $1-11$. doi:10.1016/j.jrurstud.2016.12.006

Groat, L. N., \& Wang, D. (2013). Architectural research methods (Second Edition ed.). Canada: John Wiley \& Sons, Inc.

Hidayah, N. (2011). Kesiapan Psikologis Masyarakat Pedesaan dan Perkotaan Menghadapi Diversifikasi Pangan Pokok. Humanitas, Vol. VIII No.1

Lahav, O., \& Mioduser, D. (2008). Hapticfeedback support for cognitive mapping of unknown spaces by people who are blind. International Journal of HumanComputer Studies, 66(1), 23-35. doi:10.1016/j.ijhcs.2007.08.001

Laksana, N. S. (2013). Bentuk-Bentuk Partisipasi Masyarakat Desa dalam Program Desa Siaga Di Desa Bandung Kecamatan Playen Kabupaten Gunung Kidul Provinsi Daerah Istimewa Yogyakarta. Kebijakan dan Manajemen Publik, Volume 1, Nomor 1.

Laurens, J. M. (2007). Arsitektur dan Perilaku Manusia. Jakarta: PT. Grasindo.

Majerova, H. (2015). The Aspects of Spatial Cognitive Mapping in Persons with Visual Impairment. Procedia - Social and Behavioral Sciences, 174, 32783284. doi:10.1016/j.sbspro.2015.01.994

Nopianti, R. (2016). Leuit Si Jimat: Wujud Solidaritas Sosial Masyarakat di
Kasepuhan Sinarresmi. Patanjala, Vol. 8 (No. 2), 219 - 234.

Parera, H., \& Jacob, J. M. (2016). Peningkatan Manajemen Kesehatan Babi dan Pertanian Terpadu di Kelompok Mawar dan Kelompok Lorosae. Jurnal Pengabdian Masyarakat Peternakan, Vol. 1 (No. 1 ).

Picuno, P. (2012). Vernacular farm buildings in landscape planning: a typological analysis in a southern Italian region. Journal of Agricultural Engineering, volume XLIII (e20). doi:10.4081/jae.2012.e20

Putri. (2011). Fleksibilitas Ruang dalam Tradisi Sinoman dan Biyodo sebagai Wujud Kearifan Lokal di Dusun Karang Ampel Dau Malang. Local Wisdom, Volume: III(Nomor:.I), 25 - 33.

Rahayu, S., Ludigdo, U., Irianto, G., \& Nurkholis. (2015). Budgeting of School Operational Assistance Fund Based on The Value of Gotong Royong. Procedia - Social and Behavioral Sciences, 211, 364-369. doi:10.1016/j.sbspro.2015.11.047

Rave-Arango, J. F., \& Blandón-Uribe, C. A. (2012). Structural response of buildings on mountain slopes subjected to earth pressure under seismic conditions. Paper presented at the WCEE, Lisboa.

Riyadi, A. (2013). Upaya Pemberdayaan Dan Peningkatan Keterampilan Pemulasaraan Jenazah di Wilayah Kecamatan Mijen Kota Semarang. Dimas, Vol. 13(No. 2).

Sari, K. A. L. H., Antariksa, \& Ridjal, A. M. (2015). Teritori Ruang Ritual Pada Pura Luhur Dwijawarsa Malang. student journal Arsitektur Brawijaya.

Subadyo, A. T. (2016). Arsitektur Pekarangan Suku Tengger di Kantung Taman Nasional Bromo Tengger Semeru. Paper presented at the TEMU ILMIAH IPLBI 2016.

Sugiyono. (2016). Metode Penelitian Kuantitatif,Kualitatif, dan $R \& D$. Bandung: Alfabeta.

Suliyati, T. (2012). Upacara Tradisi Masa Kehamilan dalam Masyarakat Jawa. $e$ journalundip. 
Supriyadi, B., Sudarwanto, B., \& Werdiningsih, H. (2012). In Search of the Power of Javanese Culture against the Cultural Urbanization in Kotagede, YogyakartaIndonesia. Procedia - Social and Behavioral Sciences, 68, 676-686. doi:10.1016/j.sbspro.2012.12.258

Teng, I. (2017). Bobeto Sebuah Nilai Kearifan Lokal Pembentuk Ruang Ritual antara Manusia dengan Alam di Kalaodi Tidore. Local Wisdom, 9(1), 12-22. 